\title{
Understanding gluten-free bread ingredients during ohmic heating: function, effect and potential application for breadmaking
}

\author{
Elok Waziiroh ${ }^{1,2} \cdot$ Regine Schoenlechner $^{1} \cdot$ Henry Jaeger ${ }^{1} \cdot$ Gloria Brusadelli $^{3} \cdot$ Denisse Bender $^{4}(1)$
}

Received: 7 October 2021 / Revised: 13 December 2021 / Accepted: 18 December 2021 / Published online: 7 January 2022

(c) The Author(s) 2022

\begin{abstract}
Due to the absence of gluten, several challenges arise during gluten-free (GF) bread baking, affecting the mid-and-endproduct quality. The main approach to overcome this issue is to combine certain functional ingredients and additives, to partially simulate wheat bread properties. In addition, the optimization of the baking process may contribute to improved product quality. A recent and very promising alternative to conventional baking is the use of ohmic heating $(\mathrm{OH})$. Due to its volumetric and uniform heating principle, crumb development during baking and consequently bread volume is improved, which enhances the overall GF bread quality. Depending on the GF formulation, critical factors such as the electrical conductivity and viscosity of the batter may vary, which have a significant effect on the $\mathrm{OH}$ process performance. Therefore, this review attempts to provide a deeper understanding of the functionality of GF bread ingredients and how these may affect critical parameters during the $\mathrm{OH}$ processing.
\end{abstract}

Keywords Gluten-free bread · Ingredient functionality $\cdot$ Ohmic heating $\cdot$ Electrical resistance heating $\cdot$ Electrical conductivity $\cdot$ Viscosity

Denisse Bender

denisse.bender@boku.ac.at

Elok Waziiroh

elok.waziiroh@boku.ac.at; elokwz@ub.ac.id

Regine Schoenlechner

regine.schoenlechner@boku.ac.at

Henry Jaeger

henry.jaeger@boku.ac.at

Gloria Brusadelli

gloria.brusadelli@studenti.unimi.it

1 Department of Food Science and Technology, Institute of Food Technology, University of Natural Resources and Life Sciences, Vienna, Muthgasse 18, 1190 Vienna, Austria

2 Department of Agricultural Product Technology, Brawijaya University, Malang 65141, Indonesia

3 Department of Food, Environmental and Nutritional Sciences, Università degli Studi di Milano, 20122 Milan, Italy

4 Department of Food Science and Technology, Institute of Food Science, University of Natural Resources and Life Sciences, Vienna, Muthgasse 18, 1190 Vienna, Austria

\section{Introduction}

GF products have been gaining interest among scientists, especially in Western countries, where the demand towards these products is increasing. Due to the absence of gluten, significant problems (e.g., poor handling of the batter) arise during the production of GF bread. GF batters are characterized by less viscous, cohesive, and elastic properties, compared to wheat doughs [1], which consequently lead to poor bread volume, inadequate color, and a crumbling crumb.

To overcome this problem, much research has focused on finding suitable GF formulations and baking conditions to achieve a quality comparable to wheat bread. For this purpose, different approaches have been applied, such as the use of several ingredients or additives, as well as adaptation of the processing conditions, e.g., baking technology. The most recent and promising technological approach is the use of $\mathrm{OH} . \mathrm{OH}$, also called electrical resistance heating, is an emerging technology that transforms electrical energy into thermal energy. In food, heating is mainly generated by the conductive movement of ions within the food matrix [2]. Only a few fundamental studies that successfully used $\mathrm{OH}$ for GF bread baking have been reported $[3,4]$. These 
have shown a significant improvement in bread volume and crumb properties when using this technology.

Previous studies have identified critical factors that affect $\mathrm{OH}$ of food, such as the electrical conductivity, composition, and viscosity of the food [5]. Nevertheless, fundamental knowledge about the potential role of GF ingredients during ohmic baking and subsequently on the resulting GF bread quality is still scarce. Therefore, this paper intends not only to provide an overview of available studies in this respect, but to elaborate knowledge and understanding of underlying factors that should be considered when using this technology for GF baking. Specifically, it is the aim to understand the effect of GF bread ingredients on the alteration of the electrical conductivity of the food matrix and on the resulting $\mathrm{OH}$ process to provide a fundamental theoretical basis for subsequent studies on this topic.

\section{Gluten-free batter and bread properties}

In wheat dough, gluten plays an essential role in forming a strong protein network that contributes to the desired viscoelasticity of the dough [6]. The absence of gluten has a severe impact on the rheological properties of GF batters, leading to a lower viscosity, cohesiveness, and elasticity of the batter [1]. As GF bread properties strongly rely on starch and flour properties, handling and producing the batter/bread become difficult. Most available research has focused on mimicking the gluten network by applying a wide range of ingredients and additives to improve GF bread characteristics. Starchrich ingredients, hydrocolloids, emulsifiers, and (isolated) proteins are typical ingredients that are used to provide an optimal batter and bread structure [7].

The quality of GF bread is mainly influenced by the amount and properties of starches and/or flours, which increase the foam stability of the batter by enhancing its viscosity [8]. Most GF batters have a higher water content than wheat doughs, which is necessary to ensure proper starch gelatinization upon baking [9]. The amount of water alters the rheological properties of GF batter by decreasing its solid-like behavior and reducing its viscoelastic properties (decrease of storage (G') and loss modulus (G”)). This partly influences other rheological properties such as tan $\delta$, consistency and the viscosity of (GF) batters which are important for the final bread quality. An opposite behavior is seen in gluten-containing (wheat) doughs, where the viscoelastic properties are developed without modifying the $\tan \delta\left(G^{\prime \prime} / G^{\prime}\right)$; in this case, water has a plasticizing effect on the dough [7].

The influence and effect of GF batter viscosity on resulting GF bread properties are still not fully understood yet. Previous studies have attempted to mimic the viscoelastic properties of wheat dough by adding functional ingredients to GF batter formulations (see Table 1), resulting in different effects. Some studies have reported that higher batter viscosities improve GF bread properties, while other studies found no or opposite effects. Ronda et al. [10] stated that the specific volume of GF bread was positively correlated with $\tan \delta$ and negatively correlated with the storage modulus $\left(\mathrm{G}^{\prime}\right)$. Meanwhile, Matos and Rosell [11] found that a higher dough consistency limited dough expansion, resulting in lower bread volume. It seems that a higher viscosity increases gas holding capacity and foam stability, while an exceeding viscosity in GF batters might again limit its ability to expand during proofing. Previous studies have shown that batters with a solid-like behavior generally led to higher GF bread quality, when baked conventionally. However, Waziiroh et al. [12] highlighted that in the case of ohmic baking, GF batters with liquid-like behavior were more suitable for baking with ohmic heating, as this promoted the ion movement necessary for heating. Overall, research above shows that more profound knowledge and understanding of suitable viscosity ranges for GF batter is important, but further investigations are required in this respect.

\section{Critical parameters during $\mathrm{OH}$}

$\mathrm{OH}$ is a volumetric heating method that is based on an electrical current passing through a food matrix. This principle results in faster and more uniform heating compared to conventional heating which is based on convection, conduction, and radiation. The advantages of $\mathrm{OH}$ also include a shorter processing time and a reduced overall thermal load, which may contribute to better retention of the food quality, e.g., nutritional properties [2].

Important parameters used during $\mathrm{OH}$ are the alternating current frequency, the applied voltage, the heating rate and the temperature to which the food material is heated [18-20]. Usually, high-frequency ranges above $10 \mathrm{kHz}$ are used to control the corrosion of the electrodes, as reported by several authors [19-21]. This is explained by Icier [22] as higher frequencies reduce the cycle time, which simultaneously restricts the electrochemical reactions occurring near the electrode.

According to Palaniappan and Sastry [23], the most critical property for heating food with $\mathrm{OH}$ is its electrical conductivity. Conductivity is a function of temperature, frequency, and product composition, which increases linearly with temperature [24-26]. Icier [22] highlighted that $\mathrm{pH}$, food composition, total solid content and viscosity significantly affect the electrical conductivity of liquid food. For solid-liquid foods, particle dimension, density, and the proportion of electrical conductivity of liquid and solid particles are critical factors. 


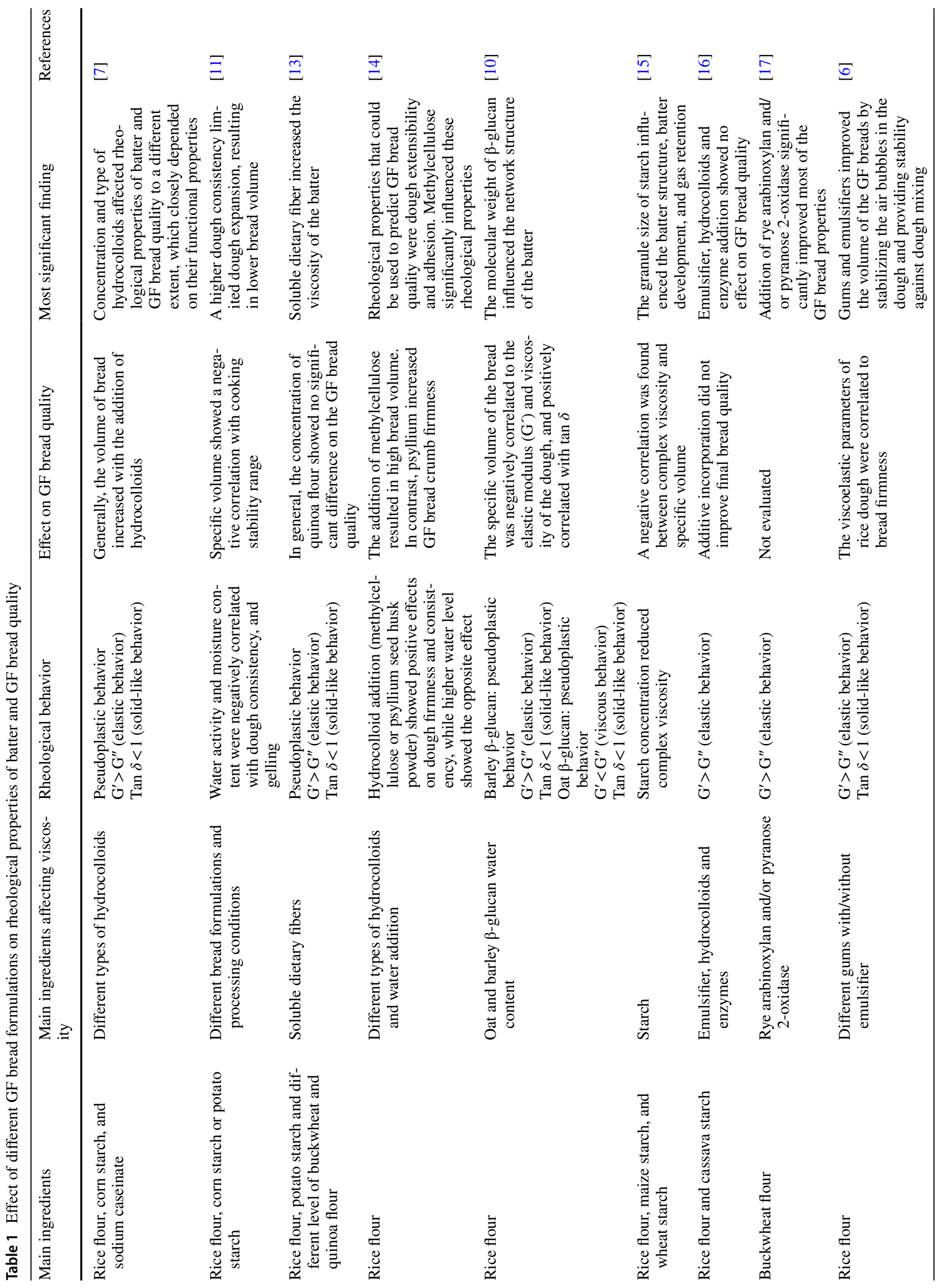


In general, $\mathrm{OH}$ depends on the conductive properties of food, especially on the ionic composition/content of the food matrix [27]. Ionic compounds such as salts and acids that are dissociated in solution into $\mathrm{Na}^{+} / \mathrm{K}^{+}, \mathrm{H}^{+}$, or $\mathrm{Cl}^{-}$ions enhance the electrical conductivity of the food matrix [27, 28]. Fryer et al. [25] stated that the efficiency of $\mathrm{OH}$ increases with salt concentration, as it changes the electrical resistance and therefore, the heating rate. In contrast, non-polar components such as fats, oil, alcohol, and sugar will decrease the electrical conductivity of the food [19, 22, 27]. Halden et al. [5] affirmed that the melting of fats and the transition of starch, as well as the cell structural changes, could also influence the electrical conductivity of the food matrix.

The total solid content and viscosity of liquid food generally affect the electrical conductivity and the $\mathrm{OH}$ rate [29]. In particular, the dissolved solid content significantly influences the consistency and, therefore, the conductivity [30]. Li et al. [31] discovered a negative correlation between the viscosity and conductivity of a starch suspension during starch gelatinization using $\mathrm{OH}$. As the viscosity of the starch suspension increased, the accessibility of unbound water decreased, reducing the mobility of the ions and electrical conductivity simultaneously, which caused a decrease in the heating rate $[32,33]$.

Waziiroh et al. [12] investigated the correlation between GF batter viscosity and electrical conductivity at $25^{\circ} \mathrm{C}$. Results showed that less viscous GF batters displayed higher electrical conductivities than those made with less water. This was explained by the higher water content of low-viscosity batters, which have a dilution effect on the ions, enhancing ion mobility and therefore reducing electrical resistance. Similarly, Li et al. [31] studied the electrical conductivity of starch during gelatinization. During heating, the electrical conductivity of starch solution increased. As the starch started to gelatinize, the electrical conductivity reached a plateau. This phenomenon could be explained due to the rapid increase of water-binding during gelatinization, which led to an increased viscosity and reduced the mobility of ions and eventually the electrical conductivity.

The application of $\mathrm{OH}$ for baking is still scarce and only few investigations have focused on bread baking (see Table 2). To successfully apply $\mathrm{OH}$ for baking, the behavior of batter ingredients on critical factors (e.g., conductivity, viscosity) during the heating process needs to be understood. This is especially challenging in bread, as this food matrix progressively transitions from a liquid to a solid-state during heating. First trials have already suggested that rapid and uniform baking enhances GF bread properties [4]. However, for full exploitation of this $\mathrm{OH}$ technology and successful application for GF baking, further detailed research is necessary to gain knowledge about the role and behavior of the batter ingredients to predict its performance during ohmic baking. Past studies have already revealed that starch, protein, salt, water, and yeast, which are major ingredients for GF bread making, significantly alter critical factors of food during $\mathrm{OH}$, which will be used as a basis for discussion in the following chapters.

\section{Effect of gluten-free batter ingredients on the ohmic heating process}

\section{Starch}

Starch and flour are the major components in GF bread. Chaiwanichsiri et al. [32] suggested that the composition of starch could influence the electrical conductivity of food during $\mathrm{OH}$. Starches contain a small amount of phosphate groups bound to amylopectin, which could serve as free ions and modify the electrical conductivity of starch during gelatinization. According to Wong et al. [28], potato starch contains significant amounts of phosphorus, more than any other starches, affecting its gelatinization temperature during $\mathrm{OH}$. The phosphorus in potato starch is a negatively charged phosphate ester that along with an electric field, could accelerate starch granule disintegration and water diffusion into the starch granule and decrease the crystalline stability during heating.

To understand how starch-rich ingredients might be affected by the $\mathrm{OH}$ process, several properties that affect starch gelatinization and swelling need to be considered, e.g., amylose/amylopectin ratio, the particle size of the starch granule, or the amount of starch damage.

Starch and flour have shown similar pasting properties when heated with $\mathrm{OH}$. However, the proportion of other components (e.g., protein, lipids) which are naturally present in the flours/starches or added to the GF formulation, will significantly affect its pasting properties. In general, lipids and GF proteins will delay the granule swelling, causing less amylose leaching and increasing the gelatinization temperature [32]. These components may also interact with amylose, delay starch gelatinization, decrease its electrical conductivity, and may increase the $\mathrm{OH}$ cooking time. An and King [39] identified a difference of the gelatinization temperature during $\mathrm{OH}$ of starch suspensions depending on their amylose content. The ratio between amylose and amylopectin affects physical properties of starch such as swelling, gelatinization, and retrogradation [40].

Additionally, He and Hoseney [37] affirmed that starch gelatinization led to less water availability, decreased ion mobility, increased dough resistance, and, consequently, decreased the electrical conductivity. Martin et al. [36] stated that the starch granules extracted from ohmic-baked bread were less swollen and not deformed compared with starch granules from conventional-baked bread. This was 
Table 2 Investigations that have used $\mathrm{OH}$ for producing or studying selected properties of baking goods

\begin{tabular}{|c|c|c|c|c|}
\hline Focus of study & Baking good & Critical parameter & Most significant finding & References \\
\hline $\mathrm{OH}$ assisted proofing & Wheat bread & $\begin{array}{l}\text { Controlling the heating rate to reduce tem- } \\
\text { perature gradients } \\
\text { Voltage intensity }\end{array}$ & $\begin{array}{l}\text { Lag phase time stage during proofing was } \\
\text { shortened, eventually reduced fermentation } \\
\text { time }\end{array}$ & {$[34]$} \\
\hline $\begin{array}{l}\text { Moisture distribution } \\
\text { within crumb }\end{array}$ & Wheat bread & $\begin{array}{l}\text { Temperature gradients } \\
\text { Crust availability } \\
\text { Amylose:amylopectin ratio }\end{array}$ & $\begin{array}{l}\text { Moisture in } \mathrm{OH} \text { breads was lower than con- } \\
\text { ventionally baked breads, as } \mathrm{OH} \text { breads were } \\
\text { crustless. Amylopectin influenced retrogra- } \\
\text { dation and water migration during storage }\end{array}$ & {$[35]$} \\
\hline Crumb formation & GF Bread & $\begin{array}{l}\text { GF bread formulation } \\
\text { Protein } \\
\text { Viscosity of batter } \\
\text { Density during fermentation }\end{array}$ & $\begin{array}{l}\text { Bread volume and crumb structure depended } \\
\text { on the balance between } \mathrm{CO}_{2} \text { release and } \\
\text { crumb setting during baking. Egg white } \\
\text { proteins improved gas cell stabilization }\end{array}$ & {$[3]$} \\
\hline Crumb firming & Wheat bread & $\begin{array}{l}\text { Baking time } \\
\text { Presence of shortening } \\
\text { Crumb moisture content } \\
\text { Moisture migration }\end{array}$ & $\begin{array}{l}\text { Crumb firmness of conventionally baked } \\
\text { breads were higher than } \mathrm{OH} \text {-baked breads } \\
\text { after } 24 \mathrm{~h} \text { of storage }\end{array}$ & {$[36]$} \\
\hline \multirow[t]{4}{*}{ Bread baking } & Wheat bread & $\begin{array}{l}\text { Temperature gradients } \\
\text { Input power } \\
\text { Porosity of batter }\end{array}$ & $\begin{array}{l}\text { Heating methods affected the } \mathrm{CO}_{2} \text { release of } \\
\text { dough. A higher dough expansion was seen } \\
\text { using } \mathrm{OH} \text {. The electrical resistance of dough } \\
\text { containing yeast was higher than dough } \\
\text { without yeast }\end{array}$ & {$[37]$} \\
\hline & Wheat bread & $\begin{array}{l}\text { Temperature } \\
\text { Salt content } \\
\text { Dough porosity }\end{array}$ & $\begin{array}{l}\text { The importance of the formulation and fer- } \\
\text { mentation of dough for the development of a } \\
\text { baking method } \mathrm{OH} \text { was highlighted }\end{array}$ & {$[38]$} \\
\hline & GF bread & Power and holding time profile during baking & $\begin{array}{l}\text { OH demonstrated better GF bread quality } \\
\text { and starch digestibility than conventionally } \\
\text { baked bread }\end{array}$ & [4] \\
\hline & GF bread & $\begin{array}{l}\text { Functional properties of starch/flour } \\
\text { Starch/flour:water ratio }\end{array}$ & $\begin{array}{l}\text { Water content or viscosity ranges influenced } \\
\text { final ohmic-baked bread properties. Tuber } \\
\text { and cereal starch/flour exhibited different } \\
\text { rheological behavior and water requirement }\end{array}$ & {$[12]$} \\
\hline
\end{tabular}

caused by insufficient water or temperature to melt starch crystallites, leading to an underbaked ohmic bread. Additionally, Bender et al. [4] highlighted that $\mathrm{OH}$ displayed a higher heating rate than conventional heating, resulting in inadequate time and water hydration of starch to swell and solubilize. This phenomenon caused improper starch gelatinization and reduced starch digestibility of ohmic-baked bread. Therefore, adjusting the starch:water ratio, power input, temperature and holding time profile of ohmic baking is considered as a critical condition for assuring suitable processing conditions and end-product quality.

Another important factor that affects electrical conductivity is the starch granule size. Morales-Sánchez et al. [33] measured the electrical conductivity of different starch suspensions with differing granule sizes, such as rice, corn, and potato starch. Smallest and largest starch granule sizes were seen in rice and potato, respectively, while corn exhibited both small and large granules. It was observed that the electrical conductivity increased with the smallest granule size (rice) and decreased with the largest granule size (potato).

Damaged starch is an important parameter that could influence the electrical conductivity of a food matrix. It represents the number of starch kernels physically broken or fragmented during the milling process. A higher amount of damaged starch caused an increase in viscosity, reduced the movement of ions, thus electrical conductivity and probably heating rate [31]. Furthermore, the amount of damaged starch was also correlated with water holding capacity (WHC) of a sample, but is not affected by the type of heating method as seen by Da Silva et al. [40]. These authors found that the WHC of an ohmic heated sample was not different from the conventionally heated starch, concluding that WHC is only affected by the starch properties and not by the heating method.

Starch can be modified by chemical, physical and enzymatic means to improve its functional properties, such as its viscosity, gelling, or pasting properties. Li et al. [31] reported that the electrical conductivity of native and pregelatinized starch differed from each other. Native starch had higher electrical conductivity than pre-gelatinized starch due to its poor solubility and lower water-binding capacity, resulting in lower slurry viscosity, specifically in cold water below $50{ }^{\circ} \mathrm{C}$. Although there are several studies that investigate the effect of $\mathrm{OH}$ on starch granule structure, no 
studies using modified starches have been carried out yet. Some studies have focused on characterizing the dielectric properties of starch. Dielectric properties are a critical variable in microwave heating that describe the interaction of food with microwave electromagnetic radiation [41-43]. It is indirectly correlated with electrical conductivity, since both are affected by similar factors such as water content, viscosity, and starch-phase transition. Miller et al. [41] investigated the dielectric properties of esterified or etherified starches with differing degrees of chemical substitution (acetate, phosphate, quaternary, and tertiary ammonium or octenylsuccinate) and at different starch-to-water ratios. Results showed that the type of chemical modification influenced the dielectric behavior of starch to a greater extent than the starch-water ratio.

\section{Dietary fiber, sugar, and hydrocolloids}

Dietary fibers (DF), sugars and hydrocolloids are commonly added to GF bread. These do not only improve the nutritional value of GF bread but also enhance some of its quality parameters like specific volume, crust color, and crumb structure [44]. The addition of DF may play a role during the $\mathrm{OH}$ process, as it will influence the viscosity of the batter due to its water holding properties. This could affect the ion mobility during $\mathrm{OH}$ as described before (see "Critical Parameters during $\mathrm{OH}$ "). Moreover, DF also affects starch gelatinization, limiting starch swelling and therefore raising its gelatinization $[45,46]$. Until now, there has been no research that characterizes how DF influences the electrical conductivity of food during $\mathrm{OH}$, but several properties (e.g., particle size, structure, and amount of available water) need to be carefully considered, especially in the case of bakery products such as GF bread.

Regarding the effect of sugar, some studies have been carried out to estimate the influence of this component on the $\mathrm{OH}$ process. Overall, it is known that sugar decreases the electrical conductivity of the food matrix due to its nonionic components [23, 47]. Makroo et al. [48] evaluated the effect of sugar on the electrical conductivity of mango puree. The result showed that sugar decreased the electrical conductivity, possibly due to the ability of sugar to bind water and increase the viscosity, limiting the ion mobility. Additionally, Poojitha and Athmaselvi [49] stated a higher concentration of sugar decreased the electrical conductivity of banana pulp. In general, sugar is widely used in yeastleavened bakery products as a substrate for yeast. As sugar is added in small amounts (2\%) in bakery products, its influence on the electrical conductivity of the batter compared to other ingredients, is questionable.

The most commonly used hydrocolloids in GF baking are hydroxypropyl methylcellulose (HPMC), carboxymethylcellulose (CMC), psyllium, carrageenan, xanthan gum, guar gum, or locust bean gum. The ability of the hydrocolloids to improve the batter properties depends on the type of hydrocolloids used, its interaction with other food components and the process conditions during baking [7]. Similar to DFs, hydrocolloids will influence the pasting properties, gelatinization, swelling and staling of GF bread [9]. Ren et al. [14] investigated the effect of methylcellulose and psyllium on the rheological properties of GF rice batter and bread quality. Apart from the type of hydrocolloid, water level should be well adjusted to obtain desirable rheological GF batter properties. High water addition levels led to low dough stability, overexpansion and weak crumb structure. In contrast, low water addition resulted in high rigidity of dough, excessive air entrapment during mixing, and restrained gas cell expansion. Both conditions showed poor GF bread quality, such as low bread volume, high crumb firmness and non-uniform pore structure.

Only a few investigations have been carried out to study the behavior of hydrocolloids during $\mathrm{OH}$. Marcotte et al. [27] studied several hydrocolloid solutions, including carrageenan, xanthan, pectin, gelatin, and starch, during ohmic heating. The results showed that the hydrocolloid concentration had a crucial influence on viscosity, and subsequently on electrical conductivity and heating rate. With increasing concentration, the apparent viscosity, electrical conductivity, and heating rate of the solutions increased, resulting in a shorter heating time.

Several factors such as ionic charges, ash content and $\mathrm{pH}$ might explain the differences in conductivity between hydrocolloids [23, 27], as seen in Table 3. Marcotte and Trigui [50]. have evaluated the effect of citric acid addition on the electrical conductivity of hydrocolloids at different $\mathrm{pH}$ values but revealed only small differences in electrical conductivity between samples. Overall, hydrocolloid properties like structure, ion charge, and ash content should be considered for ohmic heating, as they significantly affect the heating process.

\section{Protein}

Proteins are widely used in GF formulations to substitute gluten functionality and improve bread properties, such as crumb structure and volume. This improvement is attributed to its outstanding foaming properties, which stabilize and increase $\mathrm{CO}_{2}$ retention within the batter [6]. According to Wilde [54], two fundamental aspects need to be controlled during foaming: foam formation and foam stability. Foam formation is related to the number and size of gas cells in the batter, while foam stability is related to the preventive action to inhibit coalescence, drainage, and disproportion within gas cells. The formation and stability of a foam mainly rely on the functional properties of the protein, especially on its molecular weight and hydrophobic activity [54]. Lower 
molecular weights facilitate the protein diffusion to the bubble interface area, and higher protein hydrophobicity increases foam stability by lowering the surface tension between the phases. Additionally, the electrical charge of the amino acids within the protein significantly affects protein solubility, which later affects foaming, emulsification, and gelling [55].

The application of protein in GF bread (based on cassava starch, potato starch, or rice flour batters) baked by $\mathrm{OH}$ was investigated by Masure et al. [3]. They found that the addition of egg white protein improved gas cell stabilization, increased loaf volume and contributed to a finer pore structure. However, the effect of these proteins on the $\mathrm{OH}$ process was not studied. Moreover, the amount of air stabilized within the foam is decisive during $\mathrm{OH}$, as excessive bubble formation may hinder or even limit its application and decrease the electrical conductivity [38]. According to Mucchettict et al. [56], protein has a net charge, but the electrical conductivity of proteinous foods such as milk and whey is mainly due to its soluble salt fraction and water content. The contribution of protein to the electrical conductivity of milk and whey is assumed to be small.

$\mathrm{Li}$ et al. [57] investigated the effect of $\mathrm{OH}$ with different voltage on functional properties of soymilk protein. The results showed that protein structure and functional properties in soybean milk greatly changed depending on applied voltage and compared to the traditional heat treatment. However, the authors applied no comparable temperature-time profiles, so it is difficult to conclude on distinct electric field and thermal effects. Alampresse et al. [58] performed batch and continuous processing of egg protein by $\mathrm{OH}$. Despite the expected changes of egg protein resulting from thermal treatment, samples processed by $\mathrm{OH}$ showed an increased apparent viscosity, better foaming capacity and continuous $\mathrm{OH}$ treatment resulted in samples with better color retention. The authors emphasized the need to optimize applied temperature-time combinations to develop effective and efficient pasteurization processes with maximized microbial inactivation and minimized detrimental effects on functional properties.

Table 3 Ion charge and ash content of selected hydrocolloids

\begin{tabular}{llll}
\hline Hydrocolloids & Ionic charge & Ash content $(\%)$ & References \\
\hline Carrageenan & Ionic & 20.00 & {$[27]$} \\
Xanthan & Ionic & 8.70 & {$[27,51]$} \\
Psyllium & Non-ionic & 3.80 & {$[52]$} \\
Alginate & Non-ionic & & {$[53]$} \\
CMC & Non-ionic & 0.70 & {$[53]$} \\
HPMC & Non-ionic & & {$[53]$} \\
Starch & Non-ionic & 0.60 & {$[27]$} \\
\hline
\end{tabular}

Overall, it can be summarized that proteins significantly influence the foaming properties, viscosity, and electrical conductivity of food matrices. Further investigations to comprehensively explain the role of protein and its foaming properties during $\mathrm{OH}$ still need to be conducted.

\section{Fat and emulsifiers}

Small amounts of fat in bread can significantly improve bread properties, in particular in GF bread. Most GF bread contain at least twice as much fat than wheat bread. Fat components typically added to bread are shortenings, emulsifiers, or naturally present in the flour/starch ingredient. The main role of fat is to stabilize the gas cells in the GF batter during proofing. Additionally, it serves as a lubricant between the particles in the batter, decreasing resistance towards mixing by lowering batter consistency. During the first stage of baking, fat melts and hinders the water absorption of starch, which in turn delays starch gelatinization and increases the time of bread expansion [59].

According to Houben et al. [60], different types of fat influence the GF bread to a different extent, which is mainly attributed to the chemical properties of the fat. Margarine addition (solid fat, higher content of short-chain fatty acids) increases the gas binding capacity. In contrast, vegetable oil (liquid, higher content of long-chain fatty acids) decreases the starch swelling properties resulting in a softer crumb and higher bread volume. Leissner [61] highlighted that solid fat significantly influences bread volume, while no effect was seen with liquid fat. Moreover, Smith and Johansson [62] stated that a high amount of solid fat in bread decreased its staling rate. Previous studies related the effect of fat types on bread quality is displayed in Table 4.

A special consideration has to be given to fat when applying $\mathrm{OH}$, as this nutrient is a non-conductive component, which reduces the electrical conductivity of the food matrix, influencing the heating rate and thus cooking time. The fat concentration of the food matrix is very important, as it might limit the application of $\mathrm{OH}$. According to Bozkurzt and Icier [70], who studied the influence of fat during $\mathrm{OH}$ of meat, fat might also create barriers for the passage of the electrical current. Halden et al. [5] reported that the electrical conductivity of food was changed after the fat components melted in the course of $\mathrm{OH}$.

Several studies of the effect of fat on $\mathrm{OH}$ have been conducted in meat, but until now, there is no available research on the role of fat during ohmic baking. Since the electrical conductivity of the food is affected after the melting of the fat component, the source and properties of fat could play a decisive role. Different chemical compositions of the fat/oil/lipid (fatty acid spectrum: amount and chain length, degree of saturation) or its modification (e.g., fractionated, 
hydrogenated) define its physical properties like physical state (solid or liquid) or melting point/range, which should be considered, as they may have different effects during ohmic baking.

Emulsifiers are often applied in (GF) bread baking and added in small amounts (0.5-2\%). They are responsible for stabilizing batter viscosity, which improve bread volume. They also favor the development of a stable and regular bread crumb and delay bread staling, due to its ability to interact with starch, protein and fat within the bread dough/ batter [54].

From a chemical point of view, emulsifiers are lipids (e.g., lecithin, mono and di-glycerides) and show amphiphilic structures. As lipids, their effect during $\mathrm{OH}$ will be similar to lipids, exhibiting very poor electrical conductivities. As some proteins have emulsifying properties too, their effect will probably be defined by their molecular size, charge and its influence on batter viscosity as described before (see "Fat and emulsifiers"). One study of de Figueiredo Furtado et al. [71] investigated the effect of $\mathrm{OH}$ on the emulsification activity of lactoferrin. The ohmically heated lactoferrin showed a similar denaturation behavior to conventional heating. Differences were seen in the aggregation of proteins, as smaller protein aggregates were formed during $\mathrm{OH}$. The emulsion displayed less turbidity, indicating less protein aggregation during $\mathrm{OH}$, which directly affected the emulsification properties. Pereira et al. [72] stated that $\mathrm{OH}$ reduces the protein denaturation due to the absence of hot surfaces and less overheating.

Although the effect of emulsifiers on the $\mathrm{OH}$ process is mainly defined by its chemical nature, it should also be considered that emulsifiers change the properties of a batter, when using this technology for baking.

\section{Yeast}

In general, breadmaking consists of three basic steps, namely mixing, fermentation, and baking. At the initial mixing stage, ingredients are homogenized and hydrated into a batter, while physically aerating the GF batter. Trapped bubbles will play an important role, as they serve as nuclei for the later proofing stage [73]. During fermentation, the biological aeration of the batter occurs, which is mainly attributed to the production of $\mathrm{CO}_{2}$ of the yeast. Yeasts from the species Saccharomyces cerevisiae, also known as Baker's yeast, are used for this purpose, and are the main leavening agents used in bread. Besides $\mathrm{CO}_{2}$ production, ethanol and other secondary compounds are metabolized by the yeast, which later affect the volume, structure, flavor, color and shelf life of the final product [74].

Baker's yeast, which is commonly added to bread, could potentially affect $\mathrm{OH}$ of GF bread in two aspects: by directly influencing the conductivity of the food matrix, or affecting it indirectly through the production of specific yeast metabolites (e.g., $\mathrm{CO}_{2}$ ) $[38,75,76]$.

The first approach has not been widely studied, but some first insights on how yeast cells affect the conductivity of a medium have been reported before. An older study carried out by Johnson and Green [75] investigated the conductivity of yeast cells in suspension. Their results showed that yeast cells possessed different conductivities, which closely depended on the salt concentration of the media (0.1-1\% $\mathrm{NaCl})$ they were exposed to. It was explained that yeast cells could store diffusible salts in their body, which was enhanced with increasing salt concentration. Upon heating, salts were then released from the yeast cells, which altered the electrical resistance of the cells and the surrounding

Table 4 Effect of fat type on bread quality

\begin{tabular}{|c|c|c|c|}
\hline Bread flour based & Type of fat & Bread quality & References \\
\hline Amaranth & Vegetable fat & Low impact on bread structure & [63] \\
\hline Rice & Sunflower oil & Oil increased specific volume and reduced crumb firmness & [64] \\
\hline Wheat & $\begin{array}{l}\text { Glyceryl trioleate (GTO) } \\
\text { Glyceryl trimargarate }(\mathrm{GTM})\end{array}$ & $\begin{array}{l}\text { Ratio GTM:GTO 1:7 increased bread volume } \\
\text { GTO showed lowest bread volume }\end{array}$ & {$[65]$} \\
\hline Wheat & $\begin{array}{l}\text { Hydrogenated rapeseed oil } \\
\text { Hydrogenated high palmitic acid rapeseed oil } \\
\text { Monoglyceride fully hydrogenated } \\
\text { Soybean oil }\end{array}$ & $\begin{array}{l}\text { Solid lipid improved bread volume, while the liquid fat showed } \\
\text { no effect }\end{array}$ & [61] \\
\hline Wheat & Palm oil shortening based & $4 \%$ of palm oil shortening increased bread volume & {$[66]$} \\
\hline Wheat & $\begin{array}{l}\text { Fully hydrogenated soybean oil } \\
\text { Polyglycerol polyricinoleate (PGPR-90) }\end{array}$ & $\begin{array}{l}\text { Hydrogenated soybean oil increased loaf volume and decreased } \\
\text { loaf weight }\end{array}$ & {$[62]$} \\
\hline Wheat & Dry olive paste flour & Bread quality was not affected & [67] \\
\hline Wheat & $\begin{array}{l}\text { Palm oil } \\
\text { Monoglyceride-palm oil-water gel } \\
\text { Monoglyceride-sunflower oil-water gel }\end{array}$ & $\begin{array}{l}\text { Monoglycerides improved bread volume and decrease staling } \\
\text { rate }\end{array}$ & {$[68]$} \\
\hline Wheat & $\begin{array}{l}\text { Walnut oil } \\
\text { Walnut oil cake }\end{array}$ & $\begin{array}{l}\text { Walnut oil decreased bread firmness and increased bread } \\
\text { volume }\end{array}$ & [69] \\
\hline
\end{tabular}


suspension. A more recent study investigated the effect of $\mathrm{OH}$ on the structure and permeability of the cell membrane of $S$. cerevisiae [77]. It was seen that during $\mathrm{OH}$, intracellular protein materials were translocated out of the cell wall, as the electric field increased from 10 to $20 \mathrm{~V} / \mathrm{cm}$. Furthermore, it was observed that the number of proteins exuded from the cell wall of the yeasts was higher with $\mathrm{OH}$ than for conventional heating, especially at higher temperatures $\left(55-60{ }^{\circ} \mathrm{C}\right)$.

Regarding indirect effects, the influence of $\mathrm{CO}_{2}$ on the electrical conductivity of dough has been reported before, which is a key factor that should be considered when baking with $\mathrm{OH}$. According to Gally et al. [38], the electrical conductivity of dough was reduced as fermentation time and aeration progressed. This was explained by the significantly poor electrical conductivity of the gas bubbles, which enhanced the electrical resistance of the batter. Also, Kim et al. [76] monitored the $\mathrm{CO}_{2}$ production in dough fermentation by measuring its electrical resistance. It was seen that the electrical resistance of the dough rapidly increased in the early stage and gradually increased in the late stage of proofing, which was attributed to the $\mathrm{CO}_{2}$ production rate of the yeast. So overall, the amount and rate of $\mathrm{CO}_{2}$ production have a significant effect on the conductivity of the dough. These parameters can be controlled by processing and formulation (e.g. fermentation time, temperature, yeast properties and concentration) as shown by the investigations described below, and could be used to establish a suitable aeration range when using ohmic baking.

As mentioned before, a critical factor that affects fermentation is the yeast strain. According to Birch et al. [78] strains can lead to different optimal fermentation times, which can vary from 40 to $100 \mathrm{~min}$. This is explained by the different maltase activities in the yeasts, which are influenced by the cultivation method or by the different metabolizations of maltose in the yeast cells. Additionally, Struyf et al. [79], found that dried instant yeast needed a longer mixing time for rehydrating, while short mixing times were sufficient for compressed yeast to reach maximum fermentation rates. Kim et al. [76] reported that higher yeast concentrations led to higher $\mathrm{CO}_{2}$ production in the dough, which could shorten the fermentation time and reduce the electrical resistance of the dough. On the other hand, fermentation time could also be successfully reduced by reaching optimal fermentation temperatures in the batter faster, as some authors report [34, 80]. Gally et al. [34] showed that ohmic-assisted proofing decreased the lag phase of the yeast during the initial fermentation process, resulting in a reduced fermentation time from 58 to $20 \mathrm{~min}$.
Overall, there is not enough information to state whether Baker's yeast itself could significantly influence the electrical conductivity of a complex food matrix-like GF batter, but it is well-known that metabolites such as $\mathrm{CO}_{2}$ can significantly alter GF batter properties and especially its electrical conductivity. Since, the biological aeration of a batter can be controlled by several factors, such as yeast properties (strain, type, and concentration) and processing conditions (temperature and fermentation time), these factors could be used as a tool in further studies for tailoring batter aeration, which would suit ohmic baking.

Combining GF bread ingredient functionality with ohmic baking becomes a promising approach to obtain optimal GF bread characteristics. However, understanding the critical factors and the correlation between the ingredients and ohmic baking properties is challenging. This is because GF bread requires complex ingredients to develop its structure during baking. For starch and flour ingredients, the effects are related to their composition, granule size, eventual modification, accompanying compounds (e.g., ash content), and importantly to starch gelatinization occurring with increasing temperature, which majorly changes batter viscosity and porous dough/batter structure. Most polysaccharides and hydrocolloids strongly influence batter viscosity, although the temperature effect differs from starch gelatinization. Proteins are generally an important baking ingredient, additionally, they have a great influence on $\mathrm{OH}$ parameters. Electrical conductivity will be affected along with their functional properties (e.g., foam formation and stability, solubility, surface hydrophobicity) and ionic charges. In detail, protein addition aims to provide a targeted dough/batter structure. Thus, their foaming properties, which affect batter viscosity or air incorporation, may highly influence $\mathrm{OH}$ parameters, particularly heating rate. Fat and related components are important, as they are poorly conductive themselves and may thus change the electrical conductivity of the resulting batter. Also, their melting behavior during heating has to be considered. Regarding yeast, indirect factors that affect the amount and rate of $\mathrm{CO}_{2}$ (e.g., fermentation parameters, yeast properties) need to be considered, as they have a direct effect on the electrical conductivity of the batter and therefore on the $\mathrm{OH}$ process.

As the bread structure is formed, a complex relationship between ingredients and electrical conductivity take place during baking. To facilitate understanding, an overview on the influence of GF bread ingredients on batter and bread characteristics can be seen in Fig. 1. Figure 2 also describes the relationship between ingredient functionality and ohmic 
baking properties. Additionally, a summary of the investigations on the effects of GF bread ingredients on $\mathrm{OH}$ properties is presented in Supplementary Table S1.

\section{Conclusions}

$\mathrm{OH}$ has been recently used as a novel approach to improve GF bread properties. As GF bread is a complex system composed of several ingredients, this review has highlighted the need for understanding their functionality and role during ohmic baking. Their effect on critical factors of $\mathrm{OH}$, in particular electrical conductivity or heating rate, is one of the main elements to be considered for future adaptation of GF recipe parameters and $\mathrm{OH}$ conditions.

Based on the available investigations, the review has revealed that when estimating the effect of any ingredient, two major aspects have to be taken into consideration: (1) the ingredient itself will affect $\mathrm{OH}$ parameters due to its chemical composition (e.g., ionic and non-ionic compound), physical properties (e.g., starch damage, particle size, ion charge), and functional properties (e.g., swelling power, foam formation, emulsification ability, solubility, surface hydrophobicity) and (2) structural development of the ingredients during processing (e.g., starch gelatinization, protein denaturation, and foam formation) that lead to changes of viscosity, porosity and density within the dough/ batter which could influence $\mathrm{OH}$ to a great extent. The main structural development to look at in this respect is dough/ batter viscosity, foam formation, stability, or incorporation of air (pores) and induced changes of those structural properties during the ohmic heating process. All these physical parameters are desired dough/batter conditions for an improved final (GF) bread quality, but will alter electrical conductivity and, in most cases, decrease the heating rate. OH parameters need to be adapted to these changing conditions in the course of ohmic baking, requiring a tailored $\mathrm{OH}$ processing regime considering different steps with the targeted adjustment of processing parameters.

Overall, this review has identified and gathered fundamental and critical aspects that need to be considered for the application of $\mathrm{OH}$ in the field of GF baking. All single ingredients as well as their interaction within the batter and their changing physical properties during the heating phase are factors that need thorough consideration during ohmic baking. Yet, thorough research efforts have to be undertaken for a deeper understanding and more insight into their properties.

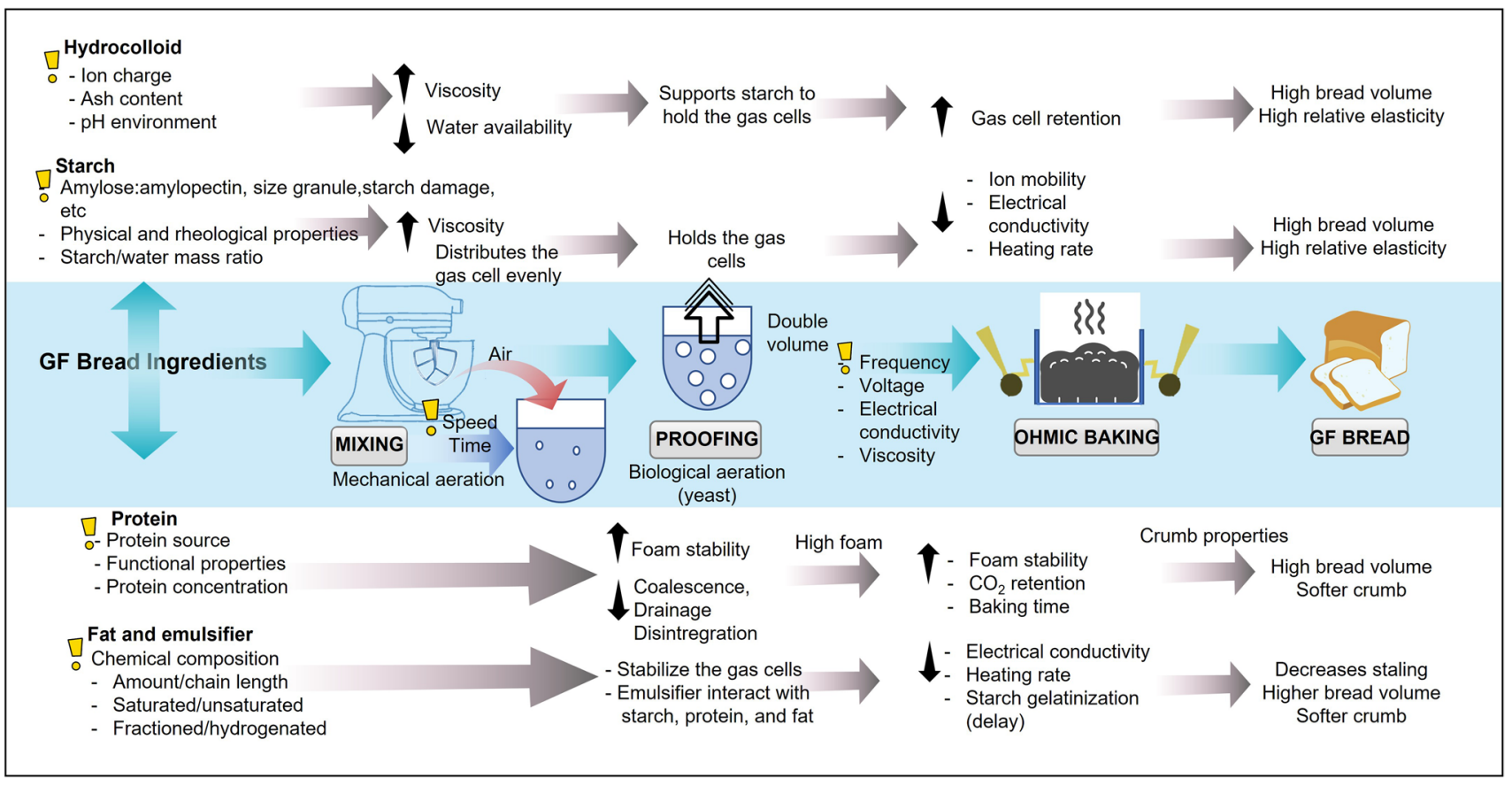

Fig. 1 Overview of the influence of the GF bread ingredients on batter and bread characteristics during ohmic baking 


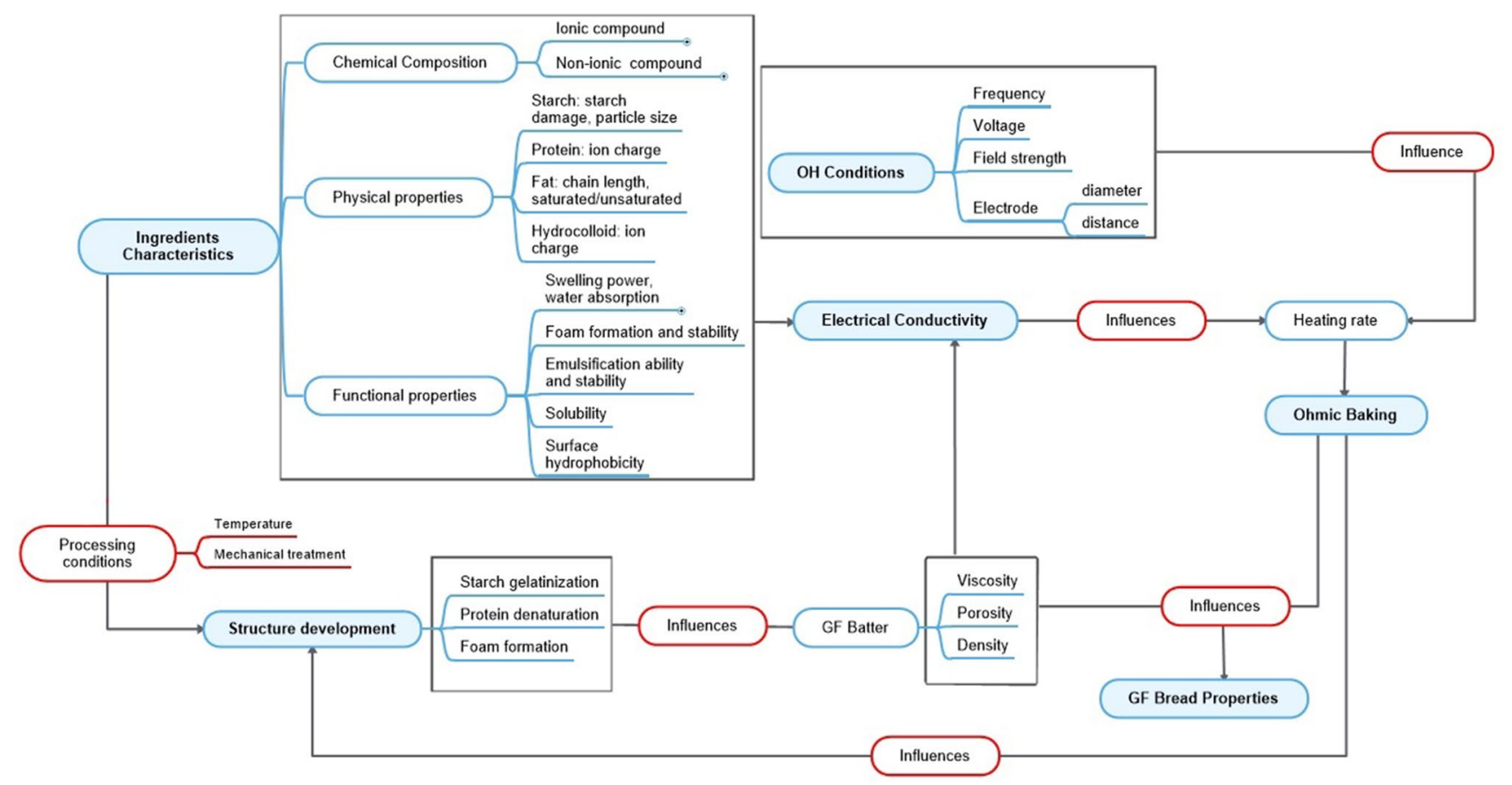

Fig. 2 Relation of ingredient functionality and ohmic heating properties with batter and bread properties

Supplementary Information The online version contains supplementary material available at https://doi.org/10.1007/s00217-021-03942-4.

Acknowledgements This work is a part of a Ph.D. program supported by the Indonesia-Austria Scholarship Programme (IASP), a joint scholarship between the Indonesian Ministry of Education and Culture (KEMDIKBUD) and Austria's Agency for Education and Internationalization (OeAD-GmbH) in corporation with ASEAN European Academic University Network (ASEA-UNINET) (reference number: ICM-2019-13886). Part of this work was also created in course of a research project of the Austrian Competence Centre for Feed and Food Quality, Safety, and Innovation (FFoQSI). The COMET-K1 competence centre FFoQSI is funded by the Austrian federal ministries BMK, BMDW and the Austrian provinces Lower Austria, Upper Austria, and Vienna within the scope of COMET-Competence Centers for Excellent Technologies. The programme COMET is handled by the Austrian Research Promotion Agency FFG. The authors would also like to thank the University of Natural Resources and Life Sciences, Vienna (BOKU) for providing the open access funding.

Author contributions Conceptualization, EW, DB, and RS; methodology, EW; investigation, EW; formal analysis, EW; resources, EW and $\mathrm{DB}$; validation, EW, DB, and RS; visualization, EW; writing —original draft preparation, EW, DB; writing - review and editing, DB, HJ, and RS. All authors have read and agreed to the published version of the manuscript.

Funding Open access funding provided by University of Natural Resources and Life Sciences, Vienna (BOKU).

Availability of data and material Data is contained within the article or supplementary material.

Code availability Not applicable.

\section{Declarations}

Conflict of interest The authors declare that they have no conflict of interest.

Ethics approval Not applicable.

Open Access This article is licensed under a Creative Commons Attribution 4.0 International License, which permits use, sharing, adaptation, distribution and reproduction in any medium or format, as long as you give appropriate credit to the original author(s) and the source, provide a link to the Creative Commons licence, and indicate if changes were made. The images or other third party material in this article are included in the article's Creative Commons licence, unless indicated otherwise in a credit line to the material. If material is not included in the article's Creative Commons licence and your intended use is not permitted by statutory regulation or exceeds the permitted use, you will need to obtain permission directly from the copyright holder. To view a copy of this licence, visit http://creativecommons.org/licenses/by/4.0/.

\section{References}

1. Matos ME, Rosell CM (2015) Understanding gluten-free dough for reaching breads with physical quality and nutritional balance. J Sci Food Agric 95(4):653-661. https://doi.org/10.1002/jsfa.6732

2. Jaeger H, Roth A, Toepfl S, Holzhauser T, Engel KH, Knorr D, Vogel RF, Bandick N, Kulling S, Heinz V, Steinberg P (2016) Opinion on the use of ohmic heating for the treatment of foods. Trends Food Sci Technol 55:84-97. https://doi.org/10.1016/j.tifs. 2016.07.007

3. Masure HG, Wouters AGB, Fierens E, Delcour JA (2019) Electrical resistance oven baking as a tool to study crumb structure 
formation in gluten-free bread. Food Res Int 116:925-931. https:// doi.org/10.1016/j.foodres.2018.09.029

4. Bender D, Gratz M, Vogt S, Fauster T, Wicki B, Pichler S, Kinner M, Jäger H, Schoenlechner R (2019) Ohmic heating - a novel approach for gluten-free bread baking. Food Bioprocess Technol 12(9):1603-1613. https://doi.org/10.1007/s11947-019-02324-9

5. Halden K, de Alwis AAP, Fryer PJ (1990) Changes in the electrical conductivity of foods during ohmic heating. Int J Food Sci Technol 25(1):9-25. https://doi.org/10.1111/j.1365-2621.1990. tb01055.x

6. Demirkesen I, Mert B, Sumnu G, Sahin S (2010) Rheological properties of gluten-free bread formulations. J Food Eng 96(2):295-303. https://doi.org/10.1016/j.jfoodeng.2009.08.004

7. Lazaridou A, Duta D, Papageorgiou M, Belc N, Biliaderis CG (2007) Effects of hydrocolloids on dough rheology and bread quality parameters in gluten-free formulations. J Food Eng 79(3):1033-1047. https://doi.org/10.1016/j.jfoodeng.2006.03.032

8. Burešová I, Kráčmar S, Dvořáková P, Středa T (2014) The relationship between rheological characteristics of gluten-free dough and the quality of biologically leavened bread. J Cereal Sci 60(2):271-275. https://doi.org/10.1016/j.jcs.2014.07.001

9. Bender D, Schönlechner R (2020) Innovative approaches towards improved gluten-free bread properties. J Cereal Sci. https://doi. org/10.1016/j.jcs.2019.102904

10. Ronda F, Perez-Quirce S, Lazaridou A, Biliaderis CG (2015) Effect of barley and oat $\beta$-glucan concentrates on gluten-free rice-based doughs and bread characteristics. Food Hydrocoll 48:197-207. https://doi.org/10.1016/j.foodhyd.2015.02.031

11. Matos ME, Rosell CM (2013) Quality indicators of rice-based gluten-free bread-like products: relationships between dough rheology and quality characteristics. Food Bioprocess Technol 6(9):2331-2341. https://doi.org/10.1007/s11947-012-0903-9

12. Waziiroh E, Bender D, Saric A, Jaeger H, Schoenlechner R (2021) Ohmic baking of gluten-free bread : role of starch and flour on batter properties. Appl Sci. https://doi.org/10.3390/app11146567

13. Turkut GM, Cakmak H, Kumcuoglu S, Tavman S (2016) Effect of quinoa flour on gluten-free bread batter rheology and bread quality. J Cereal Sci 69:174-181. https://doi.org/10.1016/j.jcs. 2016.03.005

14. Ren Y, Linter BR, Linforth R, Foste TJ (2020) A comprehensive investigation of gluten free bread dough rheology, proving and baking performance and bread qualities by response surface design and principal component analysis. Food Funct 11:5333. https://doi.org/10.1039/d0fo00115e

15. Mancebo CM, Merino C, Martínez MM, Gómez M (2015) Mixture design of rice flour, maize starch and wheat starch for optimization of gluten free bread quality. J Food Sci Technol 52(10):6323-6333. https://doi.org/10.1007/s13197-015-1769-4

16. Sciarini LS, Ribotta PD, León AE, Pérez GT (2012) Incorporation of several additives into gluten free breads: effect on dough properties and bread quality. J Food Eng 111(4):590-597. https://doi.org/10.1016/j.jfoodeng.2012.03.011

17. Bender D, Nemeth R, Cavazzi G, Turoczi F, Schall E, D'Amico S, Török K, Lucisano M, Tömösközi S, Schoenlechner R (2018) Characterization of rheological properties of rye arabinoxylans in buckwheat model systems. Food Hydrocoll 80:33-41. https:// doi.org/10.1016/j.foodhyd.2018.01.035

18. Kumar TA (2018) Review on ohmic heating technology: principle, applications and scope. Int J Agric Environ Biotechnol. https://doi.org/10.30954/0974-1712.08.2018.10

19. Varghese KS, Pandey MC, Radhakrishna K, Bawa AS (2014) Technology, applications and modelling of ohmic heating: a review. J Food Sci Technol 51(10):2304-2317. https://doi.org/ 10.1007/s13197-012-0710-3
20. Zareifard MR, Ramaswamy HS, Marcotte M, Karimi Y (2014) Ohmic heating in food processing. CRC Press Taylor \& Francis Group, Belleville. https://doi.org/10.1021/jf60052a618

21. Samaranayake CP, Sastry KS, Zhang H (2005) Pulsed ohmic heating - a novel technique for minimization of electrochemical reactions during processing. Food Eng Phys Prop 70(8):e460 e465. https://doi.org/10.1111/j.1365-2621.2005.tb11515.x

22. Icier F (2009) Influence of ohmic heating on rheological and electrical properties of reconstituted whey solutions. Food Bioprod Process 87(4):308-316. https://doi.org/10.1016/j.fbp.2009.01.002

23. Palaniappan S, Sastry SK (1991) Electrical conductivities of selected solid foods during ohmic heating. J Food Process Eng 14(3):221-236. https://doi.org/10.1111/j.1745-4530.1991.tb000 93. $\mathrm{x}$

24. Castro I, Teixeira JA, Salengke S, Sastry SK, Vicente AA (2003) The influence of field strength, sugar and solid content on electrical conductivity of strawberry products. J Food Process Eng 26(1):17-29. https://doi.org/10.1111/j.1745-4530.2003.tb00587.x

25. Fryer PJ, de Alwis AAP, Koury E, Stapley AGF, Zhang L (1993) Ohmic processing of solid-liquid mixtures: heat generation and convection effects. J Food Eng 18(2):101-125. https://doi.org/10. 1016/0260-8774(93)90031-E

26. Icier F (2012) Ohmic heating of fluid foods. In: Cullen PJ, Tiwari $\mathrm{B}$, Valdramidis $\mathrm{V}$ (eds) Novel thermal and non-thermal technologies for fluid foods. Elsevier Inc, Edinburgh. https://doi.org/10. 1016/B978-0-12-381470-8.00011-6

27. Marcotte M, Piette JPG, Ramaswamy HS (1998) Electrical conductivities of hydrocolloid solutions. J Food Process Eng 21(6):503-520. https://doi.org/10.1111/j.1745-4530.1998.tb004 66. $\mathrm{x}$

28. Wong LL, Xu YW, Lu ZH, Li-Te L (2011) Correlation of electrical conductivity and thermal properties of native starch during ohmic heating. Int J Food Eng. https://doi.org/10.2202/1556-3758. 2228

29. Kanjanapongkul K (2017) Rice cooking using ohmic heating: determination of electrical conductivity, water diffusion and cooking energy. J Food Eng 192:1-10. https://doi.org/10.1016/j.jfood eng.2016.07.014

30. Leite TS, Sastry SK, Cristianini M (2018) Effect of concentration and consistency on ohmic heating. J Food Process Eng 41(8):1-9. https://doi.org/10.1111/jfpe.12883

31. Fa-De L, Li-Te L, Li Z, Tatsumi E (2004) Determination of starch gelatinization temperature by ohmic heating. J Food Eng 62(2):113-120. https://doi.org/10.1016/S0260-8774(03)00199-7

32. Chaiwanichsiri S, Ohnishi S, Suzuki T, Takai R, Miyawaki O (2001) Measurement of electrical conductivity, differential scanning calorimetry and viscosity of starch and flour suspensions during gelatinisation process. J Sci Food Agric 81(15):1586-1591. https://doi.org/10.1002/jsfa.983

33. Morales-Sánchez E, Reyes-Vega ML, Gaytán-Martínez M, Figueroa-Cárdenas JD, Velázquez G (2015) Relationship between electrical conductivity and water activity of starch-water composites. Food Eng Ser. https://doi.org/10.1007/978-1-4939-2578-0_ 48

34. Gally T, Rouaud O, Jury V, Havet M, Ogé A, Le-Bail A (2017) Proofing of bread dough assisted by ohmic heating. Innov Food Sci Emerg Technol 39:55-62. https://doi.org/10.1016/j.ifset.2016. 11.008

35. Derde LJ, Gomand SV, Courtin CM, Delcour JA (2014) Moisture distribution during conventional or electrical resistance oven baking of bread dough and subsequent storage. J Agric Food Chem 62(27):6445-6453. https://doi.org/10.1021/jf501856s

36. Martin ML, Zeleznak KJ, Hoseney RC (1991) A mechanism of bread firming. I. role of starch swelling. Cereal Chem 68(5):498-503 
37. He H, Hoseney RC (1991) A critical look at the electric resistance oven. Cereal Chem 68(2):151-155

38. Gally T, Rouaud O, Jury V, Le-Bail A (2016) Bread baking using ohmic heating technology; a comprehensive study based on experiments and modelling. J Food Eng 190:176-184. https://doi.org/ 10.1016/j.jfoodeng.2016.06.029

39. An HJ, King JM (2006) Pasting properties of ohmically heated rice starch and rice flours. J Food Sci 71(7):437-441. https://doi. org/10.1111/j.1750-3841.2006.00138.x

40. da Silva AM, Scherer LG, Daudt RM, Spada JC, Cardozo NSM, Marczak LDF (2019) Effects of starch source and treatment type-conventional and ohmic heating - on stability and rheological properties of gels. LWT 109(April):7-12. https://doi.org/ 10.1016/j.lwt.2019.04.006

41. Miller LA, Gordon J, Davis EA (1991) Dielectric and thermal transition properties of chemically modified starches during heating. Cereal Chem 68(5):441-448

42. Motwani T, Seetharaman K, Anantheswaran RC (2007) Dielectric properties of starch slurries as influenced by starch concentration and gelatinization. Carbohydr Polym 67(1):73-79. https://doi.org/ 10.1016/j.carbpol.2006.04.017

43. Tao Y, Yan B, Fan D, Zhang N, Ma S, Wang L, Wu Y, Wang M, Zhao J, Zhang H (2020) Structural changes of starch subjected to microwave heating: a review from the perspective of dielectric properties. Trends Food Sci Technol 99(August 2019):593-607. https://doi.org/10.1016/j.tifs.2020.02.020

44. Gularte MA, de la Hera E, Gómez M, Rosell CM (2012) Effect of different fibers on batter and gluten-free layer cake properties. LWT Food Sci Technol 48(2):209-214. https://doi.org/10.1016/j. 1wt.2012.03.015

45. Brennan CS, Samyue E (2004) Evaluation of starch degradation and textural characteristics of dietary fiber enriched biscuits. Int $\mathrm{J}$ Food Prop 7(3):647-657. https://doi.org/10.1081/JFP-200033070

46. Symons LJ, Brennan CS (2004) The effect of barley $\beta$-glucan fiber fractions on starch gelatinization and pasting characteristics. J Food Sci 69(4):257-261. https://doi.org/10.1111/j.1365-2621. 2004.tb06325.x

47. Garćia-Martinez E, Ruiz-Diaz G, Martinez-Monzo J, Gamacho M, Martinez-Navarrete N, Chiralt A (2002) Jam manufacture with osmodehydrated fruit. Food Res Int 35:301-306. https://doi.org/ 10.1016/S0963-9969(01)00200-9

48. Makroo HA, Prabhakar PK, Rastogi NK (2019) Srivastava B (2019) Characterization of mango puree based on total soluble solids and acid content: effect on physico-chemical, rheological, thermal and ohmic heating behavior. LWT 103(September 2018):316-324. https://doi.org/10.1016/j.lwt.2019.01.003

49. Poojitha P, Athmaselvi KA (2018) Influence of sucrose concentration on electric conductivity of banana pulp during ohmic heating. Food Sci Technol Int 24(8):664-672. https://doi.org/10.1177/ 1082013218787069

50. Marcotte M, Trigui M, Ramaswamy HS (2000) Effect of salt and citric acid on electrical conductivities and ohmic heating of viscous liquid. J Food Process Preserv 24:389-406

51. Samutsri W, Suphantharika M (2012) Effect of salts on pasting, thermal, and rheological properties of rice starch in the presence of non-ionic and ionic hydrocolloids. Carbohydr Polym 87(2):1559-1568. https://doi.org/10.1016/j.carbpol.2011.09.055

52. Qaisrani TB, Butt MS, Hussain S, Ibrahim N (2014) Characterization and utilization of psyllium husk for the preparation of dietetic cookies. Int J Mod Agric 3(3):81-91. https://doi.org/10.17762/ ijma.v3i3.46

53. Bemiller JN (2008) Hydrocolloids. In: Arendt EK, Dal Bello F (eds) Gluten-free cereal products and beverages. Academic Press, New York. https://doi.org/10.1016/b978-012373739-7.50011-3
54. Wilde P (2012) Foam formation in dough and bread quality. In: Cauvain S (ed) Breadmaking, 2nd edn. Woodhead Publishing Limited, Sawston. https://doi.org/10.1533/9780857095695.2.370

55. Phongthai S, Singsaeng N, Nhoo-ied R, Suwannatrai T, Schönlechner R, Unban K, Klunklin W, Laokuldilok T, Phimolsiripol Y, Rawdkuen S (2020) Properties of peanut (KAC431) protein hydrolysates and their impact on the quality of gluten-free rice bread. Foods 9(7):942. https://doi.org/10.3390/foods9070942

56. Mucchetti G, Gatti M, Neviani E (1994) Electrical conductivity changes in milk caused by acidification: determining factors. J Dairy Sci 77(4):940-944. https://doi.org/10.3168/jds.S00220302(94)77029-6

57. Li X, Ye C, Tian Y, Pan S, Wang L (2018) Effect of ohmic heating on fundamental properties of protein in soybean milk. J Food Process Eng 41(3):1-10. https://doi.org/10.1111/jfpe.12660

58. Alamprese C, Cigarini M, Brutti A (2019) Effects of ohmic heating on technological properties of whole egg. Innov Food Sci Emerg Technol 58(June):102244. https://doi.org/10.1016/j.ifset. 2019.102244

59. Pareyt B, Finnie SM, Putseys JA, Delcour JA (2011) Lipids in bread making: sources, interactions, and impact on bread quality. J Cereal Sci 54(3):266-279. https://doi.org/10.1016/j.jcs.2011.08. 011

60. Houben A, Höchstötter A, Becker T (2012) Possibilities to increase the quality in gluten-free bread production: an overview. Eur Food Res Technol 235(2):195-208. https://doi.org/10.1007/ s00217-012-1720-0

61. Leissner O (1988) A Comparison of the effect of different polymorphic forms of lipid in breadmaking. Cereal Chem 3(65):202-207

62. Smith P, Johansson J (2004) Influences of the porpotion of solid fat in a shorthening on loaf volume and staling of bread. J Food Process Preserv 28:359-367

63. Schoenlechner R, Mandala I, Kiskini A, Kostaropoulos A, Berghofer E (2010) Effect of water, albumen and fat on the quality of gluten-free bread containing amaranth. Int J Food Sci Technol 45(4):661-669. https://doi.org/10.1111/j.1365-2621.2009.02154.x

64. Mancebo CM, Martínez MM, Merino C, de la Hera E, Gómez M (2017) Effect of oil and shortening in rice bread quality: relationship between dough rheology and quality characteristics. J Texture Stud 48(6):597-606. https://doi.org/10.1111/jtxs.12270

65. Bell BM, Fisher N (1997) The binding of model shortenings during mixing of mechanically developed bread doughs from fresh and stored flours. J Am Oil Chem Soc 54(11):479-483. https:// doi.org/10.1007/BF02909062

66. Chin NL, Rahman RA, Hashim DM, Kowng SY (2010) Palm oil shortening effects on baking performance of white bread. J Food Process Eng 33(3):413-433. https://doi.org/10.1111/j.1745-4530. 2008.00282.x

67. Annamaria C, Angela C, AdelN M, Amalia C (2019) Enrichment of bread with olive oil industrial by-product. J Agric Sci Technol B 9(2):119-127. https://doi.org/10.17265/2161-6264/2019.02.005

68. Manzocco L, Calligaris S, Da Pieve S, Marzona S, Nicoli MC (2012) Effect of monoglyceride-oil-water gels on white bread properties. Food Res Int 49(2):778-782. https://doi.org/10.1016/j. foodres.2012.09.011

69. Pycia K, Kapusta I, Jaworska G (2020) Walnut oil and oilcake affect selected the physicochemical and antioxidant properties of wheat bread enriched with them. J Food Process Preserv 44(8):111. https://doi.org/10.1111/jfpp.14573

70. Bozkurt H, Icier F (2010) Ohmic cooking of ground beef: effects on quality. J Food Eng 96(4):481-490. https://doi.org/10.1016/j. jfoodeng.2009.08.030

71. de Figueiredo FG, Pereira RNC, Vicente AA, Cunha RL (2018) Cold gel-like emulsions of lactoferrin subjected to ohmic heating. 
Food Res Int 103(August 2017):371-379. https://doi.org/10. 1016/j.foodres.2017.10.061

72. Pereira RN, Teixeira JA, Vicente AA (2011) Exploring the denaturation of whey proteins upon application of moderate electric fields: a kinetic and thermodynamic study. J Agric Food Chem 59(21):11589-11597. https://doi.org/10.1021/jf201727s

73. Elgeti D, Peng L, Jekle M, Becker T (2017) Foam stabilization during processing of starch-based dough systems. Innov Food Sci Emerg Technol 39:267-274. https://doi.org/10.1016/j.ifset.2016. 12.012

74. Heitmann M, Zannini E, Arendt E (2018) Impact of Saccharomyces cerevisiae metabolites produced during fermentation on bread quality parameters: A review. Crit Rev Food Sci Nutr 58(7):11521164. https://doi.org/10.1080/10408398.2016.1244153

75. Johnson IS, Green R (1924) Conductivity of yeast cells. Oxford J 34(2):186-191

76. Kim DH, Jang KA, Lee SJ (2020) Prediction method of $\mathrm{CO}_{2}$ production from electrical resistance of bread dough measured with a simple electrical multimeter in fermentation. Food Sci Biotechnol 29(2):235-241. https://doi.org/10.1007/s10068-019-00666-w
77. Yoon SW, Lee CYJ, Kim KM, Lee CH (2002) Leakage of cellular materials from saccharomyces cerevisiae by ohmic heating. J Microbiol Biotechnol 12(2):183-188

78. Birch AN, Petersen MA, Arneborg N, Hansen ÅS (2013) Influence of commercial baker's yeasts on bread aroma profiles. Food Res Int 52(1):160-166. https://doi.org/10.1016/j.foodres.2013.03. 011

79. Struyf N, Van der Maelen E, Hemdane S, Verspreet J, Verstrepen KJ, Courtin C (2017) Bread dough and baker's yeast: an uplifting synergy. Compr Rev Food Sci Food Saf 16(5):850-867. https:// doi.org/10.1111/1541-4337.12282

80. Gavahian M, Tiwari BK (2020) Moderate electric fields and ohmic heating as promising fermentation tools. Innov Food Sci Emerg Technol 64:102422. https://doi.org/10.1016/j.ifset.2020.102422

Publisher's Note Springer Nature remains neutral with regard to jurisdictional claims in published maps and institutional affiliations. 